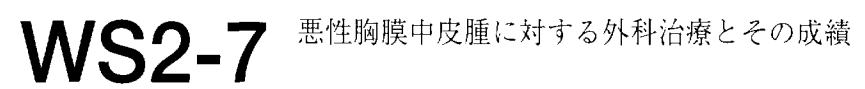

兵庫県立成人病センター 呼吸器外科

岡田 守人

悪性胸膜中皮腫は診断・治療などあらゆる面で“challenging disease”で ある。今回, 当科に扔いて組織学的に確定診断が得られ, 手術が施行 された 83 例について検討した. 男性 73 例, 女性 10 例, 年齢 $35 \sim 78$ 歳 (平均 61 歳) で，49例（59\%）にアスベスト暴露歴を有する. 組 織型は上皮型が 62 例 $(75 \%)$ と多数を占め, 肉腫型 11 例 $(13 \%)$, 混 合型 10 例 (12\%) である. IMIG 病理病期は I 期 9 例 (11\%), II 期 14 例 $(17 \%)$ ，III 期 48 例 (58\%)，IV 期 12 例 (14\%) で進行例が多 い. 術式は完全切除を企図した胸膜肺摘除術と胸膜全切除/剥皮術は それぞれ 27 例 $(33 \%)$ と 35 例 $(42 \%)$, 非完全切除の胸膜部分切除は 21 例 $(25 \%)$ であり, 手術死亡は1 例（胸膜肺摘除術後の肺梗塞）で ある。全症例の overall survival は 1 年 $55 \%, 3$ 年 $21 \%, 5$ 年 $4 \%$ であ る。組織別に2ると 3 年生存率は上皮型 $25 \%$, 混合型 $13 \%$, 肉腫型 $0 \%$ あ゙り, 術式別での 3 年生存率は胸膜肺摘除術と胸膜全切除/剥皮 術では $27 \%$ で等しく, 胸膜部分切除では 6\%である. 病期別の 3 年生 存率は I期 44\%, II 期 39\%, III 期 16\%, IV 期 0\%で，I期の 5 年生存 率は $15 \%$ である. 現時点では悪性胸膜中皮腫に対する手術療法は全 く満足できる成績ではないが，中でも上皮型・完全切除・早期症例の 予後が比較的良い。治療方針決定には確定組織診断と病期診断は最重 要であり, 完全切除と高容量放射線の組み合わせで局所を, 化学療法 の付加で局所及び遠隔をコントロールする治療戦略の確立が急務であ る.

WS3-2 肺手術の合併症をいかに防いできたか一最近の 教室での成績とそれに基づく取り組み一

福岡大学医学部第二外科

岩崎 昭憲, 山本 聡, 白石 武史, 白日 高歩

肺手術の合併症は対象患者の高齢化，それに伴う併存疾患の増大によ り以前とは異なった細心の管理が必要になってきた。多くは呼吸器・ 循環器に関連したものから術後出血や肺・脳梗塞などの重篤な病態を きたすものもある。教室では肺癌に対亦る拡大手術や低肺機能を有す る多くの呼吸器患者に手術を行ってきたが, それに伴う術中, 術後管 理に苦慮することもしばしば経験する。我々は進行肺癌に対する拡大 手術に扔いて systemic inflammatory response syndrome (SIRS) が発 症することを報告し，術前の予測因子を明らかにした。また低肺機能 を有する肺癌を Global Iinitiative for Chronic Obstructive Lung disease (GOLD) 分類に従って検討し術後合併症はやや高率であるものの安 全域などを報告してきた。このような患者背景をもとに手術適応や術 後管理を組み立てることが合併症の滅少につながると考えられる、今 回管理が困難である 80 才以上の超高齢者肺癌, 進行 T3-4肺癌, COPD 合併肺癌, 肝硬変合併肺癌の術後合併症について検討したので報告を 行う。
WS3-1

肺癌手術における mortalityをいかに減らすか 一 High volume hospitalの立場からみた周術期 管理の工夫-

国立がんセンター中央病院 呼吸器外科

渡辺俊一, 鈴木 健司, 土屋了介, 浅村 尚生

【目的】肺癌患者は高齢かつ臟器機能低下例が多く, 術死例は常に一 定の割合で存在する。しかし周術期管理を工夫することでその頻度を 隇少させることは可能である。過去の術死例の分析とそれに基づく管 理法の工夫を報告する.【方法】1981～2005 年当院にて肺癌に対し肺 切除を施行した 5,114 例に扔ける手術関連死亡率の経年推移を調査し， 詳細な記録を確認し得た 1987 年以降の死亡 63 例（同時期の肺切除 4 , 546 例）の死因を検討した.【成績】最近 5 年間（2001～2005）の 30 日死亡率は $0.36 \%(7 / 1,974)$, 在院死亡率は $0.56 \%(11 / 1,974)$ であった. 20 年前（1981～1985）洔それぞれ $1.2 \% ， 4.9 \% ， 10$ 年前 (1991～1995）は 0.5\%，2.8\%であり，在院死亡率が著明に減少し た. 死因の内訳は $1987 \sim 1996$ 年の前期 (切除 1, 615 例, 死亡 45 例) では肺炎·ARDS などの呼吸不全が $33 \%$ ，膿胸が $40 \%$ であったのに対 し，1997 - 2005 年の後期（切除 2, 931 例，死亡 18 例）はそれぞれ $44 \%, 5 \%$ であり, 膿胸による死亡が減少した、【結論】膿胸死亡の激 減が mortality 改善に最も貢献したが, 要因として肺全摘の減少と, 有 瘦性膿胸管理の改善が挙げられる。全摘後だけでなく葉切後でも積極 的に開空術を行うことで大出血や吸い込み肺炎を防ぎうる。 その他 1) 早期肺癌の增加, 2) 麻酶管理の向上，3）重喫煙者·低肺機能患者 に対する精密な肺機能評価, 術式の選択㧍よび禁煙指導, 4）肺全摘予 定患者での血流シンチ等を用いた術後肺機能予測, 5) 循環器専門医と の連携による心機能評洒，6）糖尿病患者に対する術前·後の厳密な血 糖管理などが考えられる。今後の課題は呼吸器合併症, なかでも間質 性肺炎の急性增悪をいかに予防するかである。また肺全摘後の在院死 亡率は $5 \%$ と依然高く全摘の適応は十分に検討されるべきである。

\section{WS3-3 クリニカルパス導入捘の肺癌手術合併症の検討}

癌研有明病院 呼吸器外科

奥村 栄, 松井 啓夫, 稲垣 智也, 稲垣 卓也, 佐藤 之俊, 中川 健

【目的】クリニカルパス導入後の原発性肺癌に扩ける術後合併症を検 討した【【リニカルパスの対象と概要】パスの対象は, 肺癌切除全症 例であり切除肺の程度によらず，また気管支形成例や導入化学療法施 行例も含めている。年の概要は，(1) 喫煙者に扔いては，原則として 術前 4 週間以上の禁煙. (2) 予防的抗菌薬投与は, 手術開始前に初回 投与し手術が 3 時間を超えた場合に追加投与。（3）肺塞栓予防として, 術中・術後の下肢の間歇的空気圧迫, 術当日からのへパリン投与（術 後 3 日間), 翌日からの早期離床. (4) 全身管理として, 原則術後 3 日 目（朝）に酸素投与・点滴を終了し，尿カテーテル拔去。（4）術後の 予定検查は，胸部 XP は術当日，第 1,2 病日と胸腔ドレーン抜去日と 第 7 病日. 血液検査は術翌日 $\zeta 1$ 週間後, 喀痰培養検査は第 2 病日の 1 回.【対象】クリニカルパスを導入した 2000 年以降から 2004 年まで の 5 年間で切除した原発性肺癌のうち肺葉切除あるいは肺全摘術を施 行した 594 例.【合併症の定義】合併症のうち感染症を surgical site infection（SSI）と remote infection（RI）に分類し, SSI として創感 染·肺炎・膿胸を含め, RI は surgical site 以外の感染症とした。感染 源の不明な発熱を不明熱とした。感染症以外の合併症は, 非感染性合 併症とした、結果】 5 年間の合併症率は, $20 \%(120 / 594$ 例 $)$ であっ た. 合併症の内訳は, SSI が 30 例, RI が 8 例, 不明熱が 28 例, 非感 染性合併症が 54 例でその内訳は痰喀出困難 12 例, 間質性肺炎急性增 悪 11 例，肺瘦持続 6 例，不整脈 6 例などが多くみられた。【まとめと 考察】主な合併症に関しては, 術前の背景因子からその危険因子を検 討し，その対策方法に関して検証する予定である. 